\title{
USING WALL PAINTS AS A BARRIER TO RADON GAS EMISSION
}

\author{
Ali A. Ridha, Hawraa K. Ayyed \\ Department of Physics, College of Science, University of Mustansiriyah, Baghdad, Iraq
}

(Received November 02, 2017; in final form - January 19, 2018)

\begin{abstract}
This study was aimed to calculate the radon gas emitted from inner walls of buildings using twenty-six different paint types of different origin (Iraq, Jordan, Turkey, Greece, Norway, Egypt, Germany, United States and Emirates) for environmental protection. The Radon-Scout detector was placed in a plastic container and placed at painted wall samples. The range of radon exposure was between $9 \pm 1$ and $57 \pm 4 \mathrm{~Bq} \cdot \mathrm{m}^{-3}$. Radon exposures decreased to $+74 \%$ when they were measured in terms of radon shield percentage (RSP). Radon exposures increased when the RSP dropped to $-68 \%$. This study concluded that the relationship between radon concentration and RSP depends on the type and structure of paints used.
\end{abstract}

Key words: paints, Radon-Scout, radon exposure, radon shield percentage.

DOI: https://doi.org/10.30970/jps.22.1201

PACS number(s): 28.41.Te, 47.70.-n, 89.60.Ec

\section{INTRODUCTION}

Natural radioactivity is widely spread in the earth's environment and it exists in various geological formations including soils, rocks, plants, water, air, and in building materials $[1,2]$. As it is known, most building materials of terrestrial origin contain certain amounts of natural radionuclides. These radionuclides cause external and internal types of radiation and radiation exposure [3]. The external radiation is caused by gamma-emitting radionuclides, mainly in the uranium series, which belong to the decay chain segment starting with radium Ra-226. The internal (inhalation) radiation exposure may be due to radon gas $\mathrm{Rn}-222$ (U-238 decay chain), and marginally due to its isotope thoron Rn-220 (Th-232 decay chain). Their short-lived decay products are exhaled from building materials into the room environment [4,5]. Radon $(\mathrm{Rn}-222)$ is a naturally existing radioactive gas with a half-life of 3.83 days, which can emanate from the soil as well as building materials to the indoor environment. Radon decay products of short-life progeny (Po-218, Pb214, and Bi-214) might be inhaled into the human respiratory tract and impose a significant health hazard on occupants $[6,7]$.

Radon gas easily escapes from the ground into the atmosphere and disintegrates through short-lived decay products called radon daughter or radon progeny [8]. When Rn-222 is inhaled by a human, it might be damage the lung tissue and has been identified as the second major cause of lung cancer $[9,10]$. When radium decays in soil grains, the terminal atoms of the radon isotope can escape from the mineral grains to the atmosphere. The rate of radon escape or emanation from the soil is the radon emanation rate or the radon exhalation rate. Radon emanation is a complex phenomenon depending upon a number of parameters such as radium content in soil, soil morphology, soil grain size, soil moisture, temperature, atmospheric pressure, and rainfall [11,12].

This study was designed to implement a new technique to measure radon gas concentration on painted walls with fixed dimensions (area and size) using a radioactive de- tector for 5 consecutive days. Radon-Scout device is recommended as a highly sensitive detector for radiation protection purposes, such as radon exposure from painted walls. Twenty-six painted wall samples collected from Iraqi markets where used in this study. The radon shield percentage (RSP) was proposed as a reference level for the exhalation of radon gas in painted wall samples.

\section{RADIATION COEFFICIENTS}

\section{A. Absorbed Dose Rate $\left(D_{y}\right)$}

The absorbed dose rate in $\mathrm{mSv} \cdot \mathrm{y}^{-1}$ was calculated using the following formula $[13,14]$ :

$$
D y=C_{\mathrm{Rn}} \times \epsilon \times F_{\mathrm{Rn}} \times O_{\mathrm{f}} \times T,
$$

where $C_{\mathrm{Rn}}$ is radon concentration, $\epsilon$ is the equilibrium factor $=0.4, T$ is the number of hours in a year $(T=$ $\left.8760 \mathrm{~h} \cdot \mathrm{y}^{-1}\right), O_{\mathrm{f}}$ is the occupancy factor $=0.8$ and $F_{\mathrm{Rn}}$ is the dose conversion factor $=9 \times 10^{-6} \mathrm{mSv} \cdot \mathrm{Bq}^{-1} \mathrm{~h}^{-1} \mathrm{~m}^{3}$.

\section{B. Effective Dose Rate $\left(E_{L}\right)$}

The effective dose rate for lungs due to the inhalation of radon gas has been calculated using the following equation $[15,16]$ :

$$
E_{L}=D_{y} \times W_{T} \times W_{R}
$$

where $D_{y}$ is annual absorbed dose $\left(\mathrm{mSv} \cdot \mathrm{y}^{-1}\right), W_{T}$ is tissue weighting factor for the lung $=0.12$ and $W_{R}$ is radiation weighting factors for alpha particles $=20$. 


\section{Lung Cancer Risk}

The number of lung cancer cases per million persons per year (CPPP) was obtained using the equation $[17,18]$ :

$$
\mathrm{CPPP}=\left(18 \times 10^{-6} \mathrm{mSv}^{-1} \cdot \mathrm{y}\right) \times E_{L},
$$

where $E_{L}$ is the effective dose rate in $\mathrm{mSv} \cdot \mathrm{y}^{-1}$.

\section{MATERIALS AND METHODS}

\section{A. Samples Collection and Preparation}

Twenty-six paint samples of different origins in Iraqi markets were used (Table 1). Four types of coatings including pantilayt, plastic, decorative and boya paints were selected. The commercial names of the painting types used in the current study were local. Different methods were used for painting the wall using a brush, a roller, a shovel, etc. Pantilayt, plastic and decorative samples were diluted with water, but the boya coating was diluted with a liquid thinner or oil.

After painting the walls, the radon gas detector was placed in a container and attached to the wall with an area of $0.1963 \mathrm{~m}^{2}$ for 120 hours. The dimensions of the container were: depth $=70 \mathrm{~cm}$, volume $=100 \mathrm{~L}$; the radii of the upper hole and the bottom base were $25 \mathrm{~cm}$ and $19 \mathrm{~cm}$, respectively.

\section{B. Radon Scout}

A Radon-Scout device from SARAD GmbH Company, Germany origin, model number 835 was used to measure radon gas exposure. It was placed inside a container which was in contact with the painted wall sample as shown in Figure 1. The radon monitor consists of a solid state silicon detector that reveals alpha particles emitted by radon gas and its decay products. This monitor has a dynamic range from 0 to $10 \mathrm{MBq} \cdot \mathrm{m}^{-3}$, sensitivity 0.108 $\mathrm{CPH}$ per $\mathrm{Bq} \cdot \mathrm{m}^{-3}$ and nominal $4 \mathrm{CPH}$ per $\mathrm{pCi} \cdot \mathrm{L}^{-1}$. Figure 2 shows the spectrum of Rn-222 in the Radon-Scout detector for Fab1 as a typical sample. The Radon-Scout detector has a high sensitivity to radon gas even at a low concentration. Radon gas exposure $\left(\mathrm{Bq} \cdot \mathrm{h} \cdot \mathrm{m}^{-3}\right)$, average exposure $\left(\mathrm{Bq} \cdot \mathrm{m}^{-3}\right)$, maximum exposure $\left(\mathrm{Bq} \cdot \mathrm{m}^{-3}\right)$, temperature $\left({ }^{\circ} \mathrm{C}\right)$, relative humidity $(\%)$ and measurement time (h) can be recorded from the spectrum diagram after the data passes through the instrument to a computer by specific software (SARAD).

\begin{tabular}{|c|c|c|c|c|c|c|c|c|c|}
\hline & Type of paint & Sample code & Company & Origin & $\begin{array}{c}\text { Ave. exposure } \\
\left(\mathrm{Bq} \cdot \mathrm{m}^{-3}\right)\end{array}$ & $\begin{array}{c}\text { Max. exposure } \\
\left(\mathrm{Bq} \cdot \mathrm{m}^{-3}\right)\end{array}$ & RSP (\%) & Temp. $\left({ }^{\circ} \mathrm{C}\right)$ & Hum. (\%) \\
\hline \multirow{6}{*}{ 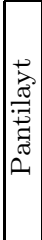 } & & Pnt1 & Al-Marjan & Iraq & $35 \pm 5$ & $92 \pm 33$ & -2.94 & 33 & 40 \\
\hline & & Pnt2 & Arabco & Jourdan & $49 \pm 4$ & $112 \pm 30$ & -44.12 & 32 & 37 \\
\hline & & Pnt3 & Cryola & Jourdan & $17 \pm 3$ & $61 \pm 41$ & +50 & 31 & 38 \\
\hline & & Pnt4 & Betek & Turkey & $37 \pm 5$ & $123 \pm 29$ & -8.82 & 29 & 41 \\
\hline & & Pnt5 & Top Primer & Greece & $9 \pm 1$ & $51 \pm 45$ & +73.53 & 35 & 39 \\
\hline & & Pnt6 & Jotun & Norway & $52 \pm 4$ & $143 \pm 27$ & -52.94 & 27 & 32 \\
\hline \multirow{5}{*}{$\mid$} & & Bo1 & Al-Marjan & Iraq & $35 \pm 5$ & $82 \pm 35$ & -2.94 & 21.5 & 35 \\
\hline & & Bo2 & Riva & Jordan & $36 \pm 5$ & $102 \pm 32$ & -5.88 & 26.5 & 36 \\
\hline & & Bo3 & Fixtone & Jordan & $23 \pm 6$ & $82 \pm 35$ & +32.35 & 29 & 40 \\
\hline & & Bo4 & Nova & Egypt & $31 \pm 5$ & $82 \pm 35$ & +8.82 & 24.5 & 39 \\
\hline & & Bo5 & Betek & Turkey & $37 \pm 5$ & $102 \pm 32$ & -8.82 & 33 & 36 \\
\hline \multirow{6}{*}{ 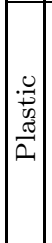 } & & Pla1 & Al-Marjan & Iraq & $20 \pm 7$ & $61 \pm 41$ & +41.18 & 28.5 & 38 \\
\hline & & Pla2 & Dylon & Jordan & $39 \pm 5$ & $92 \pm 33$ & -14.71 & 33 & 36 \\
\hline & & Pla3 & Jotun & Norway & $41 \pm 5$ & $102 \pm 33$ & -20.59 & 33.5 & 37 \\
\hline & & Pla4 & Smart Plast & Germany & $22 \pm 6$ & $62 \pm 41$ & +35.29 & 34 & 36 \\
\hline & & Pla5 & Colorplace & USA & $12 \pm 2$ & $51 \pm 45$ & +64.71 & 34 & 35 \\
\hline & & Pla6 & Mado & Jordan & $13 \pm 2$ & $61 \pm 41$ & +61.76 & 34 & 38 \\
\hline \multirow{9}{*}{$\mid$} & Fabiano & Fab & Global & Jordan & $52 \pm 4$ & $112 \pm 30$ & -52.94 & 22.5 & 41 \\
\hline & Glaze & Gla & Meraco & Jordan & $31 \pm 5$ & $72 \pm 38$ & +8.82 & 16.5 & 35 \\
\hline & Mas Crystal & Mac & Mas & UAE & $31 \pm 4$ & $82 \pm 35$ & +8.82 & 16 & 38 \\
\hline & Crackle varnish & $\mathrm{Crv}$ & Fira Color & Turkey & $27 \pm 6$ & $92 \pm 33$ & +20.59 & 16 & 42 \\
\hline & Lumbar varnish & Luv & Arteco & Turkey & $57 \pm 4$ & $143 \pm 27$ & -67.65 & 16.5 & 73 \\
\hline & Gypsum Filler & Gmf & Fixtone & Jordan & $54 \pm 4$ & $133 \pm 28$ & -58.82 & 15 & 61 \\
\hline & Stoucco & Sto & Sandeco & Germany & $52 \pm 4$ & $112 \pm 30$ & -52.94 & 16 & 59 \\
\hline & Oteshinto & Ote & Fira Color & Turkey & $37 \pm 5$ & $112 \pm 30$ & -8.82 & 16.5 & 63 \\
\hline & Acrylic & Acr & Meraco & Jordan & $34 \pm 4$ & $123 \pm 29$ & -26.47 & 14 & 56 \\
\hline & & & & Max. & $57 \pm 4$ & $143 \pm 27$ & +73.53 & 35 & 73 \\
\hline & & & & Min. & $9 \pm 1$ & $51 \pm 45$ & -67.65 & 14 & 32 \\
\hline
\end{tabular}

Table 1. Type of the paints, sources and parameters of radon-scout device and calculation of RSP. 


\section{RESULTS AND DISCUSSION}

In the present study, a novel method of radon exposure measurement was used by pasting the container onto the painted wall. This method leads to the exact calculation of radon gas from the external influences, such as changes in the temperature humidity and ventilation rate inside buildings.

The effect of coating or paint on the emanation of radon gas can be expressed by radon shield percentage (RSP) values. RSP (\%) of radon gas represents the amount of shielding afforded by the coatings from the emanation of radon gas emitted from the walls. In the present study, RSP was calculated with the help of the following equation:

$$
\operatorname{RSP}(\%)=100-\left(\left(C_{\mathrm{Rn}} / C_{\mathrm{Rn}(\mathrm{B} . \mathrm{G})}\right) \times 100\right),
$$

where $C_{\mathrm{Rn}}$ is radon gas exposure after painting the wall. Also, the average exposure of background $C_{\mathrm{Rn}(\mathrm{B} . \mathrm{G})}$ before the painting of the wall was $\left(34 \mathrm{~Bq} \cdot \mathrm{m}^{-3}\right)$. The negative sign in the RSP result denotes a decrease in the paint shielding from the emanation of radon gas, while the positive sign denotes an increase in the paint shielding from the emanation of radon gas.

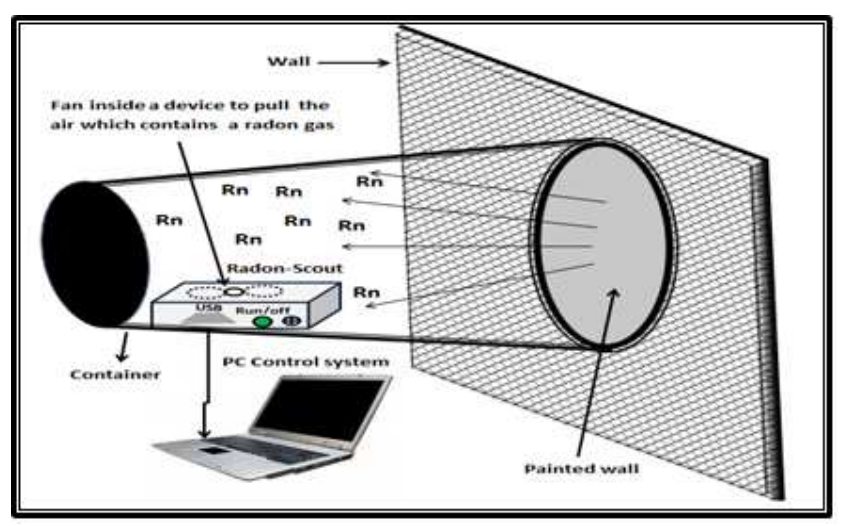

Fig. 1. The mechanism of radon gas measurement using Radon-Scout.

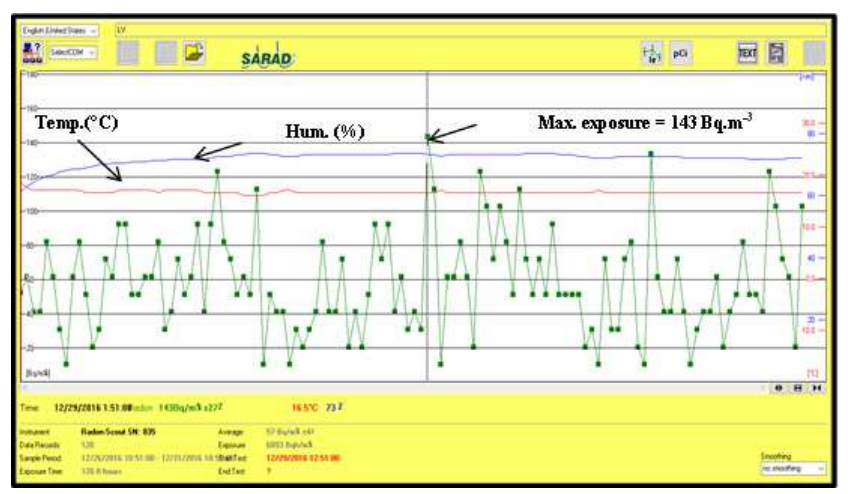

Fig. 2. The spectrum of Rn-222 using Radon-Scout for (Luv) a typically.
The average of the radon exposure was ranged from $57 \pm 4 \mathrm{~Bq} \cdot \mathrm{m}^{-3}$ in Luv sample to $9 \pm 1 \mathrm{~Bq} \cdot \mathrm{m}^{-3}$ in Pnt5 sample (Table 1). Figure-3 shows the average exposure to radon gas for each coated wall sample. Three samples Pnt6, Fab and Sto have the same value of RSP $(-52.94 \%)$. However, different values of maximum radon concentrations were found for $\operatorname{Pnt10}\left(143 \mathrm{~Bq} \cdot \mathrm{m}^{-3}\right)$ and Fab and Sto $\left(112 \mathrm{~Bq} \cdot \mathrm{m}^{-3}\right)$. This means that the biological hazard of Pnt6 is higher than the biological hazard of Fab1 and Sto. The maximum value of the radon gas shield percentage was $(+73.53 \%)$ in Pnt5 sample (Greek origin). Whereas the minimum value was $(-67.65 \%)$ in Luv Turkish sample. Figure 4 shows the percentage of radon shield for each coated wall sample.

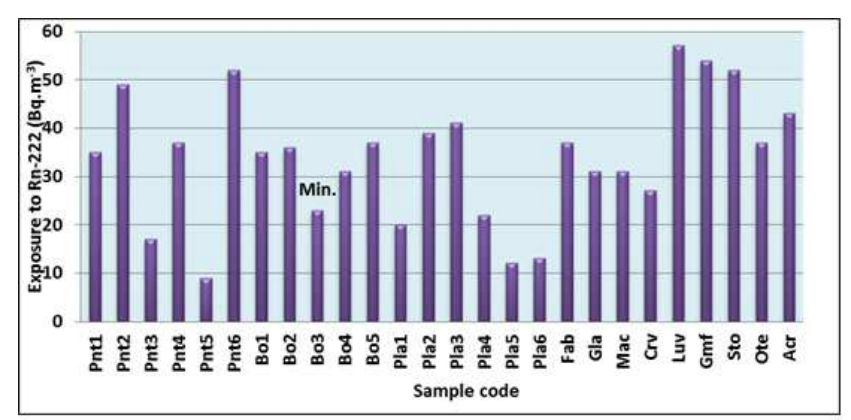

Fig. 3. Radon gas exposure for 26 coated wall samples used.

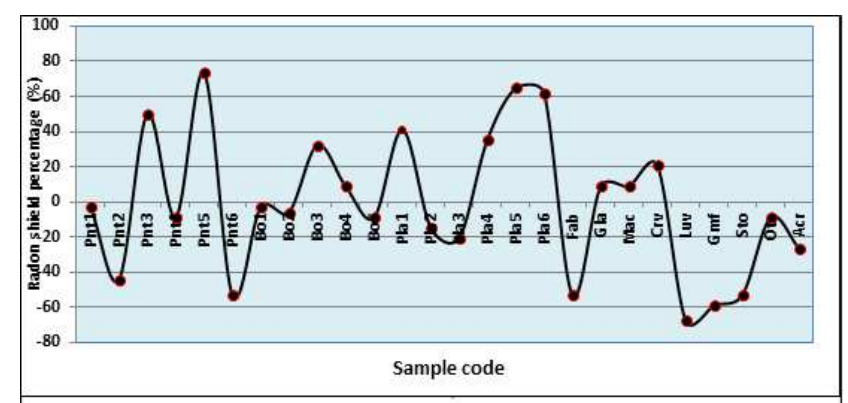

Fig. 4. Radon shield percentages for 26 samples used.

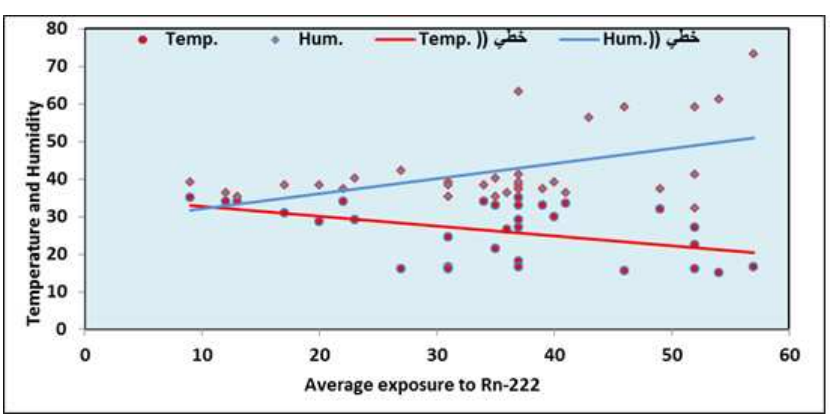

Fig. 5. The relationship between relative humidity and temperature against and radon exposure.

The effect of relative humidity on radon exhalation rate from different paints used in Iraq has been estimated using Radon-Scout measurement equipped humidity control system. In general, the radon concentration increased with an increase in relative humidity. Although 
the measuring was made in a closed container, there was an increase in relative humidity for decoratively painted wall samples. The variation in relative humidity may be due to the fact that some samples were measured in winter season and other samples were measured in summer season. The temperature tended to be linear but no clear effects on radon exposure were observed because the measuring was made in a closed container (Fig. 5).

\begin{tabular}{|c|c|c|c|}
\hline Sample code & $D_{y}(\mathrm{mSv} / \mathrm{y})$ & $E_{L}(\mathrm{mSv} / \mathrm{y})$ & $\mathrm{CPPP}$ \\
\hline Pnt1 & 0.88 & 2.12 & 38.15 \\
\hline Pnt2 & 1.24 & 2.97 & 53.40 \\
\hline Pnt3 & 0.43 & 1.03 & 18.53 \\
\hline Pnt4 & 0.93 & 2.24 & 40.33 \\
\hline Pnt5 & 0.23 & 0.54 & 9.81 \\
\hline Pnt6 & 1.31 & 3.15 & 56.67 \\
\hline Bo1 & 0.88 & 2.12 & 38.15 \\
\hline Bo2 & 0.91 & 2.18 & 39.24 \\
\hline Bo3 & 0.58 & 1.39 & 25.07 \\
\hline Bo4 & 0.78 & 1.88 & 33.79 \\
\hline Bo5 & 0.93 & 2.24 & 40.33 \\
\hline Pla1 & 0.50 & 1.21 & 21.80 \\
\hline Pla2 & 0.98 & 2.36 & 42.51 \\
\hline Pla3 & 1.03 & 2.48 & 44.69 \\
\hline Pla4 & 0.56 & 1.33 & 23.98 \\
\hline Pla5 & 0.30 & 0.73 & 13.08 \\
\hline Pla6 & 0.33 & 0.79 & 14.17 \\
\hline $\mathrm{Fab}$ & 1.31 & 3.15 & 56.67 \\
\hline Gla & 0.78 & 1.88 & 33.79 \\
\hline Mac & 0.78 & 1.88 & 33.79 \\
\hline Crv & 0.68 & 1.63 & 29.43 \\
\hline Luv & 1.44 & 3.45 & 62.12 \\
\hline Gmf & 1.36 & 3.27 & 58.85 \\
\hline Sto & 1.31 & 3.15 & 56.67 \\
\hline Ote & 0.93 & 2.24 & 40.33 \\
\hline Acr & 1.08 & 2.60 & 46.87 \\
\hline Maximum & 1.44 & 3.45 & 62.12 \\
\hline Minimum & 0.23 & 0.54 & 9.81 \\
\hline
\end{tabular}

Table 2. Absorbed dose rate $\left(D_{y}\right)$, effective dose rate $\left(E_{L}\right)$ and lung cancer cases per million person per year (CPPP) for each samples.

Table 2 shows the risk coefficients that represent the biological effects of radon gas and its progeny on the human body. The maximum value of lung cancer risk was 62.1 cases per million persons per year in Luv sample, while the minimum value was 9.8 cases in Pnt9 sample. Figure 6 shows the lung cancer risk per $10^{6}$ persons per year (CPPP) for each paint sample which was less than the lower limit of admissible range (170-230) given by (ICRP, 1993) [19]. The best type of paints recommended for painting inner walls surfaces of buildings were Pnt2, Pnt5, Pla5 and Pla6 samples, which probably may reduce the radon gas emanation (RSP) by $50 \%$ to $74 \%$. The present results recommend avoiding using Pnt6, Fab, Gmf and Luv samples, due to their contamination with various ratios of uranium-238, which cause an increase in radon emanation of up to $-68 \%$. The results obtained in this work were in good agreement with our previous studies which were done by using CR-39 detectors [20].

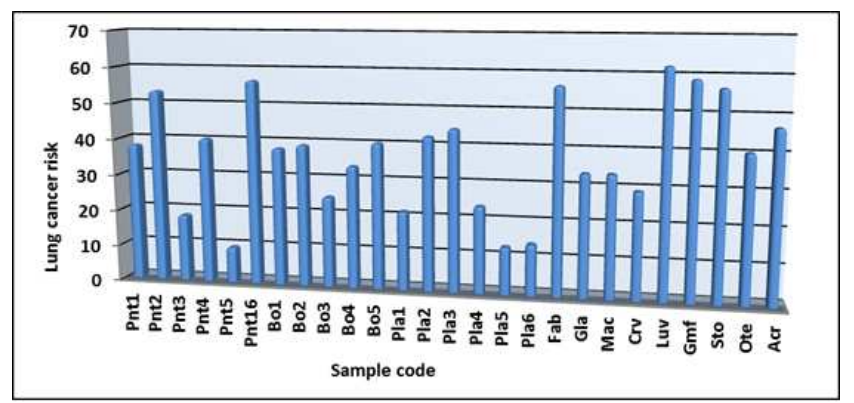

Fig. 6. Cancer risk per million persons per year for 26 samples used.

\section{CONCLUSIONS}

The Radon-Scout method showed a high effectiveness in measuring radon concentrations as the measurement time increased. The parameter (RSP) was important to know the safest types of paints to be used. The plastic paint samples have the highest percentage of radon shield as well as the PN3 and PN5 samples of pantilayt paint. The decorative paints have the lowest shield percentage from radon gas. The differences might be due to the structure of the paint samples used for painting the wall. However, the current study found that all paint samples used were safe for construction materials because the concentrations of radon gas were below the global limits $200-300 \mathrm{~Bq} \cdot \mathrm{m}^{-3}[21]$ and Canadian guideline limit of $200 \mathrm{~Bq} \cdot \mathrm{m}^{-3}[22]$.

\section{ACKNOWLEDGMENTS}

The authors wish to thank Dr. Nada Farhan Kadhim from the Radioactivity Laboratory and Dr. Firas Sabeh Mohamed from the Laser Laboratory at the College of Science, the University of Mustansiriyah, for their support.
[1] H. Kayakoku, S. Karatepe, M. Dogru, Appl. Radiat. Isot. C 115, 172 (2016).

[2] R. Varshney et al., Indian J. Pure Appl. Phys. 48, 473 (2010).

[3] K .Kovler, J. Environ. Radioact. 168, 46 (2017).

[4] A. M. Abdallah, M. Mohery, Saud J. Yaghmour, S. H. Alddin, Radiat. Phys. Chem. 81, 1710 (2012).
[5] Sources and effects of ionizing radiation. Volume I (United Nations Scientific Committee on the Effects of Atomic Radiation, 2008).

[6] L. Zhang, X. Lei, Q. Guo, Sh. Wang, X. Ma, Z. Shi, J. Radiol. Prot. 32, 315 (2012).

[7] A. A. Elzain, Adv. Appl. Sci. Res. 6, 96 (2015).

[8] N. F. Salih, Z. M. Jafri, M. Sh. Aswood, J. Radiat. Res. 
Appl. Sci. 9, 332 (2016).

[9] J. M. Stajic, D. Nikezic, J. Radioanalyt. Nucl. Chem. 303, 1943 (2015).

[10] Radon and health. Fact sheet no. 291 (World Health Organization, 2014).

[11] R. M. Amin, J. Radiat. Res. Appl. Sci. 8, 516 (2015).

[12] M. S. Khan, D. S. Srivastava, A. Azam, Environ. Earth Sci. 67, 1363 (2012).

[13] A. A. Mowlavi, M. R. Fornasier, A. Binesh, M. de Denaro, Environ. Monit. Assess. 184, 1085 (2012).

[14] L. Oufni, M. A. Misdaq, M. Amrane, Radiat. Meas. 40, 118 (2005).

[15] H. A. Yousef, A. H. EL-Farrash, Q. Merza, A. Abu-Ela,
Int. J. Phys. Res. 5, 36 (2015).

[16] R. K. Kakati, J. Appl. Phys. 613 (2014).

[17] L. A. Najam, N. F. Tawfiq, R. Hesham Mahmood, Int. J. Phys. 1, 73 (2013).

[18] A. K. Hashim, L. A. L. A. Najam, A. F. Hadi, F. K. Fuliful, World Scientific News 77, 163 (2017).

[19] Against radon-222 at home and at work. ICRP Publication 65 (Pergamum Elsevier Publication, 1993).

[20] A. A. Ridha, H. K. Ayyed, N. F. Kadhim, Nucl. Medicine 2(2), 8 (2017).

[21] Lung cancer risk from radon and progeny and statement on radon. ICRP Publication 115 (ICRP, 2010).

[22] Radon reduction guide for Canadians. Canadian national radon proficiency program (Health Canada, 2014).

\section{ВИКОРИСТАННЯ ФАРБ ДЛЯ СТІН ЯК БАР'ЄРА ДЛЯ ВИПРОМІНЮВАННЯ РАДОННОГО ГАЗУ}

Алі А. Різа, Гавраа К. Айєд

Коледж точних наук, Університет Алъ-Мустансірія, Багдад, Ірак

Це дослідження було спрямоване на розрахунок радону, що випромінюється з внутрішніх стін будівель, на яких використано двадцять шість типів фарб різного походження (Ірак, Йорданія, Туреччина, Греція, Норвегія, Єгипет, Німеччина, США та OAE) для захисту навколишнього середовища. Детектор Radon-Scout було поміщено у пластиковий контейнер та розміщено на стіні. Діапазон опромінення радону становив від $9 \pm 1$ до $57 \pm 4 \mathrm{~Bq} \cdot \mathrm{m}^{-3}$. Ці значення зменшилися до $74 \%$, коли їх вимірювали у відсотках від радонного щита (RSP). Експозиція радону збільшилася, коли RSP знизився до -68 \%. Це дослідження показало, що зв'язок між концентрацією радону та RSP залежить від типу та структури використаних фарб. 